\title{
児童の投運動学習効果に影響を及ぼす要因
}

\author{
高本 恵美 ${ }^{1)}$ 出井 雄二 ${ }^{2}$ 尾縣 貢 ${ }^{3)}$

\section{Factors influencing on learning effects of overhand-throwing ability and motion in elementary school children}

\author{
Megumi Takamoto ${ }^{1}$ Yuzi Dei ${ }^{2}$ and Mitsugi Ogata ${ }^{3}$
}

\begin{abstract}
A study was conducted to clarify factors that influence the learning effect of overhand-throwing, focusing on physical fitness and throwing motion before learning. Twenty-two boys and 24 girls in the second grade of elementary school, and 24 boys and 29 girls in the fifth grade carried out a learning program comprising four kinds of teaching materials. To improve their throwing motion, they carried out the program seven times for 15-20 min as a physical education class during a three-week period. Tennis ball throwing distance was measured, and the subjects' throwing motions were videotaped and evaluated by the observation method. At the same time, physical fitness and imitation ability were tested. As there was no significant correlation between the learning effect of throwing motion, and physical fitness and imitation ability in the group of second grade girls, it was thought that proper acquisition of throwing motion led to the improvement of throwing distance. In the group of fifth grade boys, those with a lower physical fitness level showed a large throwing motion learning effect. In the second grade boys and fifth grade girls groups, the imitation ability of the lower limb was one of the factors that influenced the learning effect. These results suggest that proper motor learning of overhand throwing has the possibility of improving throwing ability, and that some conditions present before learning, such as throwing motion, physical fitness and imitation ability, influence the degree of the learning effect.
\end{abstract}

\section{Key words : motor ability, throwing motion, physical fitness, imitation ability}

(Japan J. Phys. Educ. Hlth. Sport Sci. 49: 321-333, July, 2004)

\footnotetext{
1) 大阪体育大学

干 590-0496 大阪府泉南郡熊取町朝代台 1-1

2) 茨城県結城郡石下町立飯沼小学校

₹ 300-2746 茨城県結城郡石下町鴻野山 874-1

3）筑波大学体育科学系

T 305-8574 茨城県つくば市天王台 1-1-1

連絡先 高本恵美

1. Osaka University of Health and Sport Sciences 1-1 Asashirodai, kumatoricho, Osaka 590-0496

2. Iinuma elementary school 1364 Konoyama, Ishigemachi, Ibaraki 300-2746

3. University of Tsukuba, Institute of Health and Sport Science

1-1-1 Tennodai, Tsukuba, Ibaraki 305-8574

Corresponding author megu@ouhs.ac.jp
} 
キーワード：運動能力，投動作，体力，模倣能力

\section{I 緒言}

今回改訂された小学校学習指導要領（文部省, 1998）では，体育の目標として，基礎的・基本的 な運動技能を身に付けることが挙げられている。 そして，基礎的・基本的な運動技能の習得を図る ために，小学校低学年から中学年にかけて学習内 容として「基本の運動」が組み入れられている. これは, 幼児・児童期は神経系の発達が著しく (Scamon，1930)，技能習熟には適切な時期であ るという見解からすると至極当然なことである. そして，新たに，小学校高学年から「体つくり運 動」の内容が盛り込まれた。なかでも「体力を高 める運動」は，動きの発達を前提とした体力の発 達の促進を強調するものであり,このことからも， 小学校全学年を通じて動きつくりが強調, 重視さ れていることが分かる。

これまでに小学校児童を対象に運動学習が技能 の習得に及ぼす効果を検討した研究は，数多く行 われ（Dusenberry，1952；宮下ほか，1977；奥 野ほか，1989），児童期は運動学習に適切な時期 であるという知見が得られている。しかし，同じ 運動学習を行った児童のなかにも，その技能の習 熟には大きな個人差が生じてくることは経験上明 らかなことであり，実際の教育現場において頭を 悩ませることである。

これまでに検討されてこなかった児童間に生じ る運動学習効果の差や, その学習効果の差を生み 出す要因を明らかにすることができれば，幼览 期・児童期の体育学習の在り方について重要な示 唆を得ることができる。また，学習効果に影響を 及ぼす諸要因を予め明らかにしておき，それらを 修得させるような基礎的・基本的な運動学習を幼 児期や児童期に実施することが，学習指導要領で 強調されている「個人の能力・発達段階に応じた 課題の設定」につながってくるものと考えられる. 本研究では，基本的運動のなかでも最も技術構
造が複雑なことなどから，その発達には学習が大 きく影響するとされる投運動，なかでもオーバー ハンドスロー（海老原ほか, 1983 ; Nelson et al., 1986）を取り上げ，動作改善を目的とした学習プ ログラムを実施し，その学習効果の差に影響を及 ぼす要因について，学習前の体力や模倣能力，投 動作の発達度の面から検討した。

\section{1方法}

\section{1. 対象者}

茨城県結城郡石下町 I 小学校に在籍する第 2 学 年 2 クラス児童 46 名（男子 22 名，女子 24 名）, および第 5 学年 2 クラス児童 53 名（男子 24 名, 女子 29 名）を対象とした。対象者の身体特性は, 表1に示した。

\section{2. 投運動学習プログラム}

本研究では，投動作の改善を目指して，伊与田 （1999）および尾縣ほか（2001）の内容を参考に, 以下の方法により投運動学習プログラムを実施し た。

1) 流 れ

投運動学習プログラムは，体育授業の導入とし て実施し，一回の授業につき約 $15-20$ 分程度の 時間を充てた。1時間目および 9 時間目は，テニ スボール投げの遠投距離の測定とビデオ撮影を実 施した。2時間目は，投運動学習プログラムのオ リエンテーションとして, どすこいバウンド投げ, 振り子投げ，バトン投げ，かに走り投げの 4 種類 の教材の説明および実践を行った（図 1 参照)。 3 - 5 時間目の 3 時間は，どすこいバウンド投げ および振り子投げを，6-8時間目の 3 時間は, バトン投げおよびかに走り投げを実施した。なお， 本研究の実施期間は, 平成 14 年 5 月 20 日から平 成 14 年 6 月 13 日であった。

2) 内 容

バトン投げでは, 長さ $20 \mathrm{~cm}$ 直径 $3 \mathrm{~cm}$ のビニー ルパイプにウレタンシートを巻きつけた手製バト 
表 1 被検者の身体特性および体力テスト結果

\begin{tabular}{|c|c|c|c|c|}
\hline & \multicolumn{2}{|c|}{ 小学校 2 年生 } & \multicolumn{2}{|c|}{ 小学校 5 年生 } \\
\hline & $\begin{array}{c}\text { 男子 } \\
n=22\end{array}$ & $\begin{array}{c}\text { 女子 } \\
n=24\end{array}$ & $\begin{array}{c}\text { 男子 } \\
\mathrm{n}=24\end{array}$ & $\begin{array}{c}\text { 女子 } \\
n=29\end{array}$ \\
\hline \multirow[t]{2}{*}{ 身長（m） } & 1.225 & 1.225 & 1.377 & 1.400 \\
\hline & 0.005 & 0.005 & 0.006 & 0.007 \\
\hline \multirow[t]{2}{*}{ 体重（kg） } & 25.5 & 24.4 & 32.7 & 36.8 \\
\hline & 5.8 & 6.5 & 4.9 & 10.5 \\
\hline \multirow[t]{2}{*}{ 月齢（月） } & 91.7 & 92.3 & 128.3 & 127.5 \\
\hline & 3.4 & 3.6 & 3.5 & 3.5 \\
\hline \multirow[t]{2}{*}{ 50m 走（秒） } & 11.03 & 11.67 & 9.15 & 9.74 \\
\hline & 1.05 & 0.93 & 0.77 & 0.64 \\
\hline \multirow[t]{2}{*}{ 立ち幅跳び（cm） } & 119.36 & 111.17 & 149.17 & 142.86 \\
\hline & 18.39 & 17.11 & 15.14 & 18.55 \\
\hline \multirow[t]{2}{*}{ 握力（kg） } & 11.18 & 9.73 & 16.46 & 17.07 \\
\hline & 2.36 & 2.05 & 2.98 & 4.29 \\
\hline \multirow[t]{2}{*}{ 長座体前屈 $(\mathrm{cm})$} & 25.64 & 35.33 & 31.08 & 36.76 \\
\hline & 4.55 & 5.53 & 5.49 & 6.20 \\
\hline \multirow[t]{2}{*}{ 上体おこし（回） } & 13.32 & 11.84 & 18.5 & 16.72 \\
\hline & 3.44 & 4.50 & 4.25 & 4.14 \\
\hline \multirow[t]{2}{*}{ 反復横とび（回） } & 27.18 & 27.58 & 43.75 & 41.83 \\
\hline & 2.63 & 3.67 & 4.75 & 5.48 \\
\hline \multirow[t]{2}{*}{ 20m シャトルラン（回） } & 20.41 & 13.50 & 65.74 & 45.79 \\
\hline & 10.92 & 4.79 & 20.01 & 19.10 \\
\hline
\end{tabular}

上段：平均值 下段：標準偏差

ンを使用し，それ以外の教材では硬式テニスボー ルを使用した。

特別な投運動学習経験がない者では, 適切な投 射角度で投げ出すことが投射初速度向上とともに 投能力を高めることにつながる（尾縣・関同， 1994)。 そこで, 本研究では, 図 2 のような装置 を作成し，適切な投射角度で投げ出すための工夫 を取り入れた，地面から最上部のひもまでの高さ は $4.25 \mathrm{~m}$, 幅 $0.85 \mathrm{~m}$ の 6 つのゾーンを設定し, 最 上部のひもを越えれば 5 点，次のゾーンは 4 点, 下にいくほど 3 点， 2 点，1点，0点とした. どす こいバウンド投げでは装置から $3 \mathrm{~m}$ 離れた線から 地面に向かって投げ，その他の教材では装置から $6 \mathrm{~m}$ 離れた線から投げ，通過したゾーンに対して 得点を与え，ゲーム性を持たせた。

3）教師の関与

学習時の児童への教師の言葉かけは，各教材に おいて予想されるつまずきに対応するあらかじめ
設定された簡単な指導ポイントのみとした（表 2).

\section{3. テニスボール投げ}

投運動学習プログラム実施前後の遠投距離の測 定と投動作の撮影を，次の要領で実施した。

1) ビデオ撮影

「できるだけ遠くへ思いきり投げる」という指 示のもと， $2 \mathrm{~m}$ のサークル内からテニスボール投 げを実施し， $1 \mathrm{~cm}$ 単位で記録の計測を行った。 試技回数は 5 投とし，それぞれの試技を，サーク ルの中心点から投射方向に向かって右側方 $25 \mathrm{~m}$ の位置よりデジタルビデオカメラ（Sony 社製, VX-2000，60コマ/秒）により撮影した。最も記 録の良かった 1 試技をビデオ分析の対象とした。

2）ビデオ分析

投動作の評価には，表 3 に示した高本ほか （2003）の作成した観察的評価法を用いた．投運 
どすこいバウンド投げ
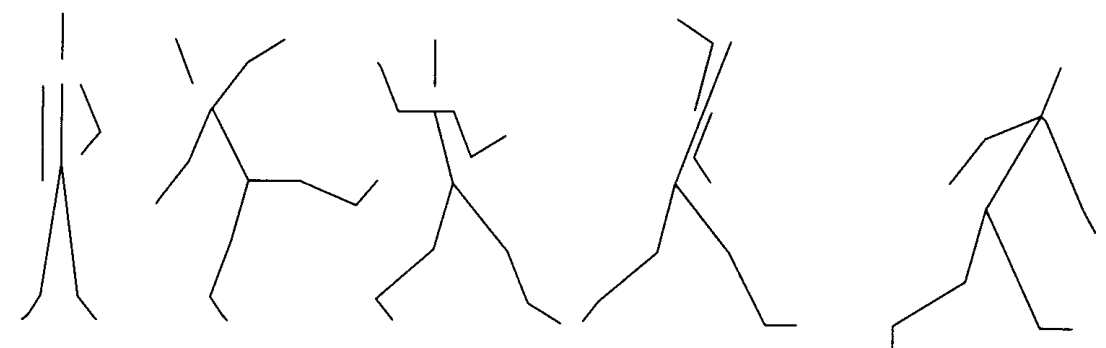

横向きの姿勢から，相撲の四股を踏む要領で，軸足と反対側の足を大きくあげ，勢いよく振り下 ろすと同時に地面めがけてボールを投げつける．体重移動の感覚，全身を使ってボールを投げる 感覚を養うことをねらいとする。

振り子投げ・バトン投げ
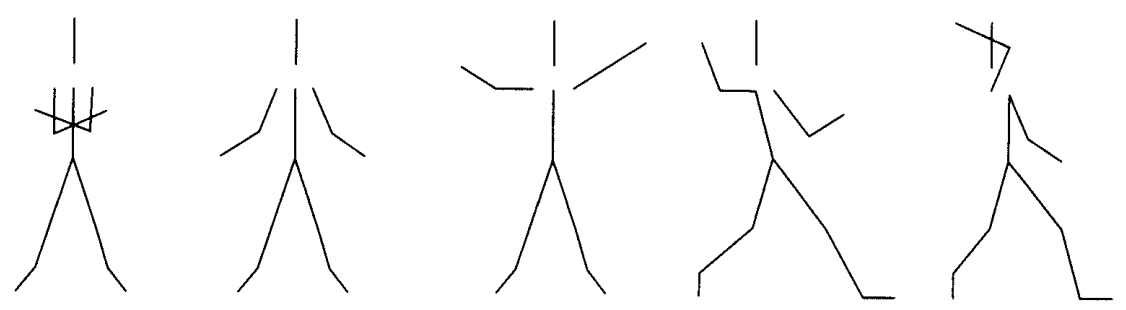

横向きに立ち，胸の前で両手首を交差させた姿勢から，肘を伸ばしながら雨腕を円を描くように 体側に振り，両手を肩の高さよりも高く挙げた姿勢から一気に投げに移行する.主動作で时がボ ールより先行し，リリース前に一気に前腕が振り出されるム千動作を引き出し，肩の回転を促進 すること（振り子投げ），バトンを縦にできるだけ多く回転させることで，スナップを強調する こと(バトン投げ) を枋らいする.

かに走り投げ
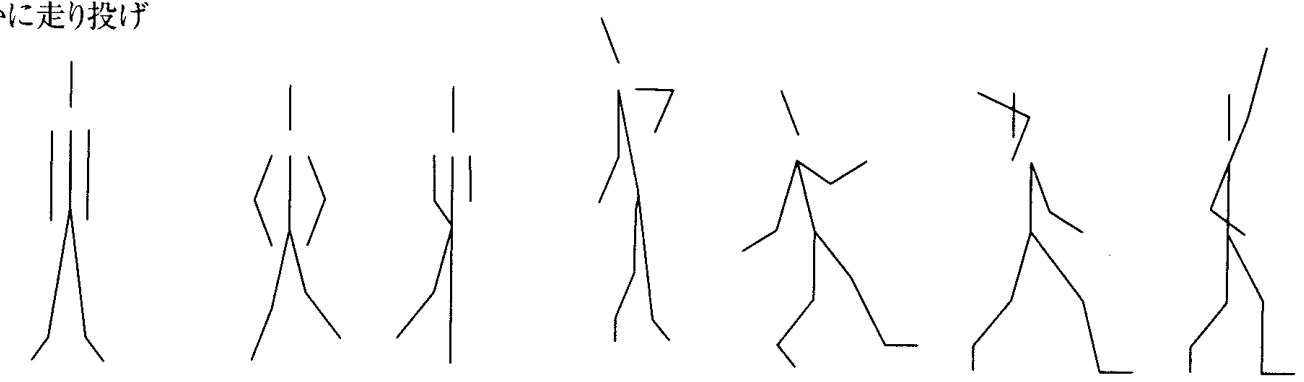

横向きの姿勢から，投射方向へサイドステップを行った後に投げる．準備動作における脚動作（ス テップ）を習熟させること，主動作における下肢と上肢の動きの連結を円滑にすることをねらい とする。

図 1 各教材の説明

動学習プログラム実施前後の試技について，動作 の評価を行った。ただし，高本ほか（2003）は， 最も未熟な動作をパターン 1 , 最も成熟した動作 をパターン 5 として, 全 5 パターンからなる動作 パターンの分類を行い, 各パターンに1点から 5 点の動作得点を与えるという方法により, 投動作
全体を5段階で評価している。そそのた，学習プ ログラムの実施により投動作が部分的に改善され ていても,動作得点に反映されない可能性がある. そこで, 本研究では, 動作評価法で示された 7 項 目の動作要素について個々に5段階評価による得 点化を行い, 全動作要素の総計動作得点を算出し, 


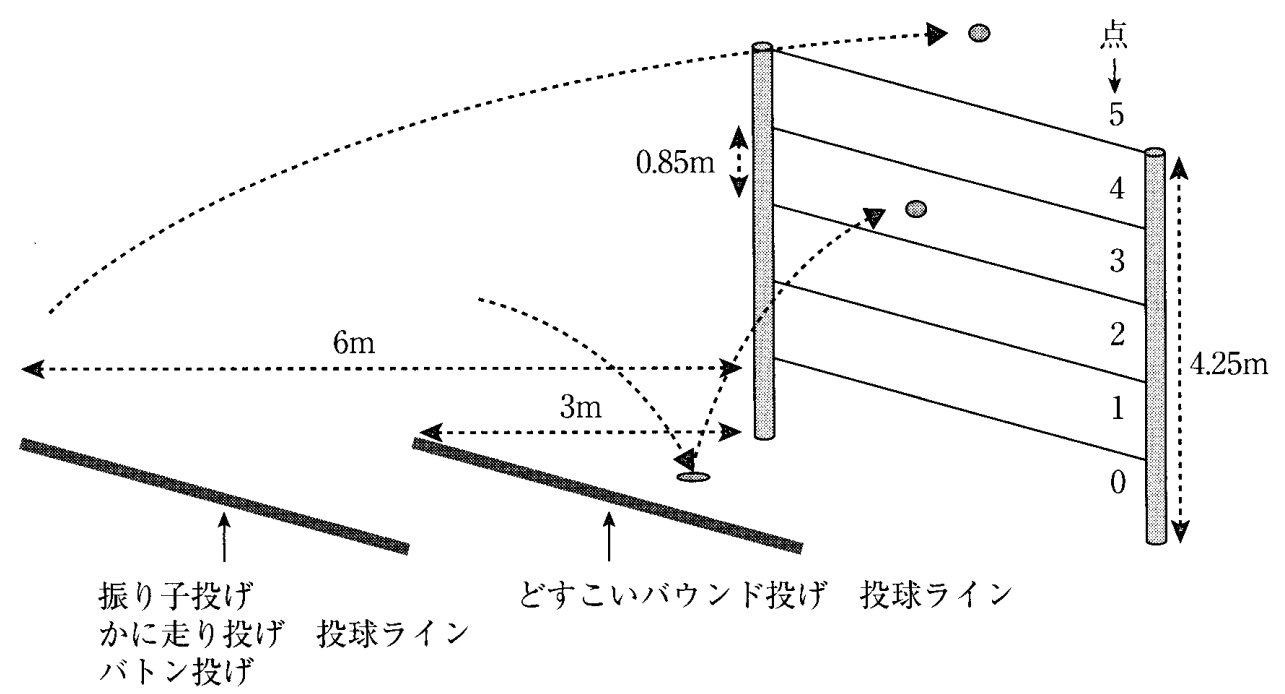

図2 投運動学習プログラムで用いた装置の設定条件

表 2 投運動学習プログラムの各教材において予想されるつまずきに対応する指導ポイント

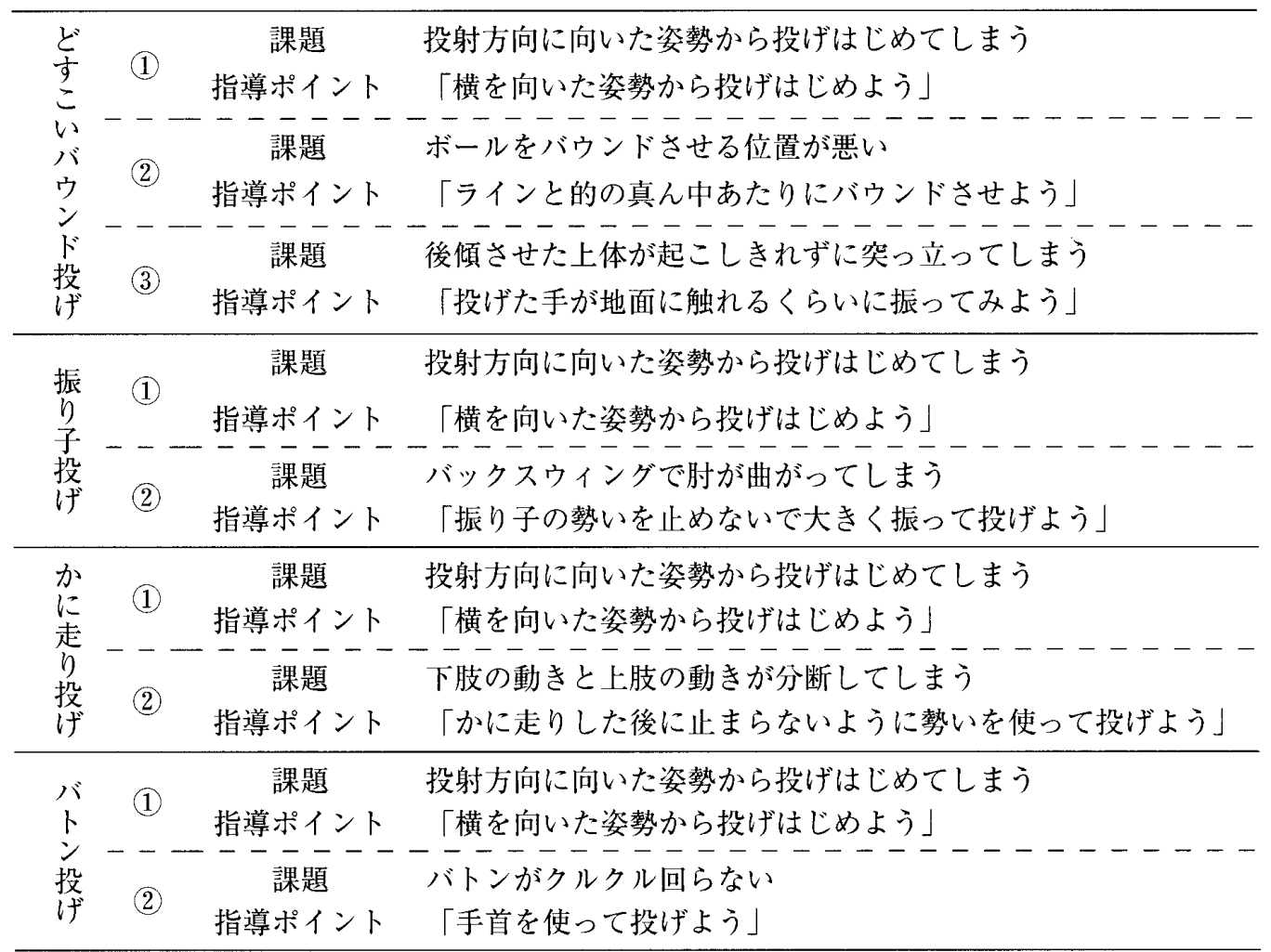

これを動作得点の指標として用いることとした.

\section{4. 体カテスト}

文部科学省体力テスト実施要領にしたがって, $50 \mathrm{~m}$ 走, 立ち幅跳び, 握力, 上体おこし, 長座 体前屈，反復横とび，および $20 \mathrm{~m}$ シャトルラン を実施し，記録を測定した。体力を総合的に評価
するために, 項目ごとに, 各対象者の各学年男女 別グループ内におけるTスコアを算出し，全測 定項目のTスコアの平均值を体力の指標として 用いることとした。

\section{5. 模倣能力テスト}

体育授業における児童の運動学習に影響を与え 
表 3 投動作の観察的評価基準

\begin{tabular}{|c|c|c|c|c|c|}
\hline & $\begin{array}{c}\text { パターン } 1 \\
(1 \text { 点 })\end{array}$ & $\begin{array}{c}\text { パターン } 2 \\
(2 \text { 点 })\end{array}$ & $\begin{array}{c}\text { パターン } 3 \\
(3 \text { 点 })\end{array}$ & $\begin{array}{c}\text { パターン } 4 \\
(4 \text { 点 })\end{array}$ & $\begin{array}{c}\text { パターン } 5 \\
(5 \text { 点 })\end{array}$ \\
\hline 投げ手腕 & $\begin{array}{l}\text { 身体前面で保持 } \\
\text { した肘を屈曲さ } \\
\text { せたまま肘を前 } \\
\text { 下方に伸展させ } \\
\text { る }\end{array}$ & $\begin{array}{l}\text { 时を屈曲させた } \\
\text { まま上方へ引き } \\
\text { 上げ，肘を前下 } \\
\text { 方へ伸展させる }\end{array}$ & $\begin{array}{l}\text { 时を屈曲させた } \\
\text { まま上腕を外 } \\
\text { 転・水平内転さ } \\
\text { せて, 後方へ引 } \\
\text { き上げる }\end{array}$ & $\begin{array}{l}\text { 手首を反時計回 } \\
\text { り循環させな } \\
\text { がら後方へ引き } \\
\text { 上げるが, 肘の } \\
\text { 伸展が不十分 }\end{array}$ & $\begin{array}{l}\text { 肩を中心として䏚 } \\
\text { を反時計回りに循 } \\
\text { 環させながら,肘を } \\
\text { 伸展させ,肩のライ } \\
\text { ンう後方に引き, } \\
\text { バックスウィング } \\
\text { の最終局面で掌を } \\
\text { 下に向ける }\end{array}$ \\
\hline $\begin{array}{l}\text { バックスウイング } \\
\text { 時体幹後傾 }\end{array}$ & 後傾していない & $\begin{array}{l}\text { ほとんど後傾し } \\
\text { ない }\end{array}$ & $\begin{array}{l}\text { わずかに後傾す } \\
\text { る }\end{array}$ & 後傾している & $\begin{array}{l}\text { 大きく後傾してい } \\
\text { る }\end{array}$ \\
\hline フォロースルー & $\begin{array}{l}\text { フォロースルー } \\
\text { がみられない }\end{array}$ & $\begin{array}{l}\text { ほとんどフォ } \\
\text { ロースルーがみ } \\
\text { られない }\end{array}$ & $\begin{array}{l}\text { わがかにォ } \\
\text { ロースルーがみ } \\
\text { られる }\end{array}$ & $\begin{array}{l}\text { 前下方への十分 } \\
\text { なフォロース } \\
\text { ルーがみられる }\end{array}$ & $\begin{array}{l}\text { 肩を水平内転させ } \\
\text { ながらの投げ手逆 } \\
\text { 側の前下方への } \\
\text { フォロースルーが } \\
\text { みられる }\end{array}$ \\
\hline 体重移動 & 体重移動しない & $\begin{array}{l}\text { ほとんど体重移 } \\
\text { 動しない }\end{array}$ & $\begin{array}{l}\text { 体重移動はして } \\
\text { いるが,投射時, } \\
\text { フォロースルー } \\
\text { 時ともまだ不十 } \\
\text { 分 }\end{array}$ & $\begin{array}{l}\text { 投射時の体重移 } \\
\text { 動は十分である } \\
\text { が, フォロース } \\
\text { ルー時はまだ不 } \\
\text { 十分 }\end{array}$ & $\begin{array}{l}\text { 全体を通して後方 } \\
\text { から前方への完全 } \\
\text { に体重移動してい } \\
\text { る }\end{array}$ \\
\hline 足の踏み出し & 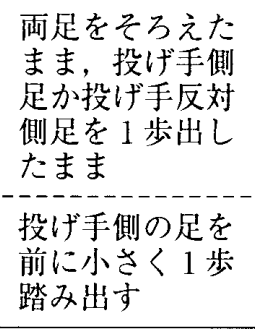 & $\begin{array}{l}\text { 投げ手側足か投 } \\
\text { げ手反対側足を } \\
\text { 前に小さく } \\
\text { 踏み出す }\end{array}$ & $\begin{array}{l}\text { 投げ手側足か投 } \\
\text { げ手反対側足か } \\
\text { ら前方へステッ } \\
\text { ブする }\end{array}$ & $\begin{array}{l}\text { 投げ手㑡足か投 } \\
\text { げ手反対側足か } \\
\text { ら前方へステッ } \\
\text { ブする }\end{array}$ & $\begin{array}{l}\text { 投げ手側足か投げ } \\
\text { 手反対側足から前 } \\
\text { 方へステップし,大 } \\
\text { きく1歩踏み出す }\end{array}$ \\
\hline \multirow[t]{2}{*}{ 体幹回転 } & $\begin{array}{l}\text { 投射方向へ正対 } \\
\text { したままで体幹 } \\
\text { は回転しない }\end{array}$ & $\begin{array}{l}\text { 投射方向へ体幹 } \\
\text { は正対したまま } \\
\text { で,肩がわずか } \\
\text { に回転する }\end{array}$ & $\begin{array}{l}\text { バックスウィン } \\
\text { グ時に後方へ回 } \\
\text { 転する }\end{array}$ & $\begin{array}{l}\text { バックスウイン } \\
\text { グ時に後方へ回 } \\
\text { 転する }\end{array}$ & $\begin{array}{l}\text { バックスウィング } \\
\text { 時に投射方向のラ } \\
\text { インより後方へ大 } \\
\text { きく回転する }\end{array}$ \\
\hline & & & & $\begin{array}{l}\text { 投射時の前万へ } \\
\text { の捻り杘しの回 } \\
\text { 転がみられる }\end{array}$ & $\begin{array}{l}\text { 投射時に,肩を水平 } \\
\text { 肉転させながら，回 } \\
\text { 転させる }\end{array}$ \\
\hline 投げ手反対腕 & 下げたまま & $\begin{array}{l}\text { 前下方へ小さく } \\
\text { 出す }\end{array}$ & $\begin{array}{l}\text { 前方へ突き出す } \\
\text { が, 投射時の体 } \\
\text { 幹方向への引き } \\
\text { 戻しはみられな } \\
\text { い }\end{array}$ & $\begin{array}{l}\text { 前方へ突き出し, } \\
\text { 投射時に体幹方 } \\
\text { 向へ引き庆す }\end{array}$ & $\begin{array}{l}\text { 前上方へ突き出し, } \\
\text { 投射時に体幹方向 } \\
\text { へ引き戻す }\end{array}$ \\
\hline
\end{tabular}

注）反時計回りとは，被検者の右側方より観察した場合

る教師の重要な行動として，示範と言語教示が挙 げられる（松田，1979；尾縣ほか，1992）。その 示範の有効性を決定する上で重要な要因の一つと して, 児童の示範行動に対する反応，すなわち運 動を模做する正確性が挙げられる，つまり，教師 によって適切な示範が実践されていることを前提 条件として，児童にその示範された動作を正確に 模倣する能力が身に付いていることが，運動学習 の効果を高める上では非常に重要であると考えら
れる。

\section{1）試 技}

模做能力テストは，高本ほか（2003）の方法を 参考に実施した，上肢の模倣能力の評価には肩関 節外転運動を，また下肢の模倣能力には立位での 股関節屈曲運動を用いた。上肢テストについて 10 回，下肢テストについては 8 回の模倣対象とな る基準動作を写し込んだVTR画像をモニター画 面に提示し，被検者には提示された動作の模倣を 
行わせた。なお，提示する 10 回あるいは 8 回の 基準動作は，すべて異なる動作角度（肩関節外転 角度 25.9 度加 89.0 度, 股関節屈曲角度 21.5 度か ら 49.1 度）の運動とし，ランダムに提示すること により，同一運動の反復による学習の影響を受け ないよう配慮した。

実験開始前に一斉に，テスト直前にも個別にテ スト内容および実施方法についての説明を行い, 「テレビ画面に写った映像のまねをして，腕（脚） を同じ高さまであげてください」という指示をし た。特に低学年の被検者に対しては，テスト実施 中，モニター画面から注意をそらさないように十 分配慮した。

デジタルビデオカメラ（Sony 社製，DCRVX2000）を用いて，上肢テストでは被検者の後 方 $10 \mathrm{~m}$ の地点から，下肢テストでは被検者の右 側方 $10 \mathrm{~m}$ の地点から試技を撮影した。

2) ビデオ分析

パーソナルコンピュータ（Sharp 社製, X68030 PRO）により，画像中の身体位置の座標 点を算出した。上肢模倣能力を評価するために， 肩峰と尺骨菱突点を結んだ線と地面に対して鉛直 方向に延びる線とがなす角を肩関節角度，また， 下肢模做能力を評価するために，大転子と外果を 結んだ線と地面に対して鉛直方向に延びる線とが なす角を股関節角度として，両関節角度を算出し た。

模倣能力テストで被検者に対して提示されたモ デルの動作における関節角度と，対象者によって 模倣された関節角度との䛊差の絶対值（以下，絶 対誤差とする）を算出した，そして，上肢につい ては，1回目から 10 回目，下肢については 1 回目 から8回目の絶対誤差の平均值を算出し，これを 上肢模倣能力および下肢模倣能力とした。

\section{6. 統計処理}

学習前後における遠投距離および投動作得点の 平均值の差を検定するために，対応のある $\mathrm{t}$ 検定 を用いた。また，遠投距離および投動作得点の学 習前後の差と各項目との間での相関関係を検討す るために, Kendallの順位相関係数を算出した.

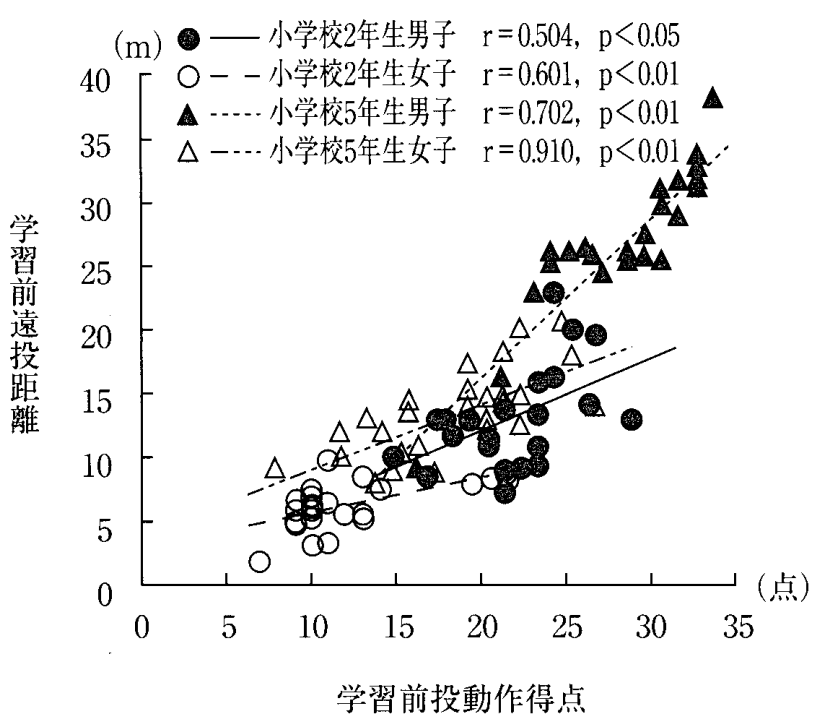

図 3 投運動学習プログラム実施前の投動作得点と遠投距 離との関係

なお，有意水準は $5 \%$ 未満とした.

\section{III 結 果}

投能力は，小学校の段階ですでに大きな男女差 が認められる能力である（金・松浦，1988； Nelson et al., 1986)。そこで，すべての項目に関 して，男女別に示すこととする。

本研究では，高本ほか（2003）の作成した投動 作の観察的評価法を用い，そこで示された7項目 の動作要素それぞれについて5段階評価による得 点化を行い, 全動作要素の動作得点の総計得点を 算出し，これを動作習熟度の指標として用いるこ ととした。図 3 に示したように，各群内での総計 動作得点と学習前遠投距離との間には有意な関係 が認められた。したがって，総計動作得点により 動作の発達を評価することの妥当性は高いと考え られるため, 総計動作得点を個々の投動作習熟度 の指標として用いることとし，これ以降，総計動 作得点を投動作得点と表記することとする.

\section{1. 投運動学習プログラムによる遠投距離およ び投動作得点の改善}

表 4 には，投運動学習プログラム実施前後の遠 投距離および投動作得点の平均値および標準偏差 を示した。 
表 4 投運動学習プログラム実施前後における遠投距離および投動作得点の比較

\begin{tabular}{|c|c|c|c|c|c|}
\hline & & \multicolumn{2}{|c|}{ 小学校 2 年生 } & \multicolumn{2}{|c|}{ 小学校 5 年生 } \\
\hline & & $\begin{array}{c}\text { 男子 } \\
n=22\end{array}$ & $\begin{array}{c}\text { 女子 } \\
n=24\end{array}$ & $\begin{array}{c}\text { 男子 } \\
\mathrm{n}=24\end{array}$ & $\begin{array}{c}\text { 女子 } \\
n=29\end{array}$ \\
\hline \multirow[t]{4}{*}{ 遠投距離（m） } & 学習前 & 12.78 & 6.25 & 26.53 & 13.22 \\
\hline & & 3.96 & 1.89 & 5.63 & 3.23 \\
\hline & 学習後 & 13.58 & 7.54 & 27.18 & 14.35 \\
\hline & & 3.75 & 1.90 & 5.45 & 3.62 \\
\hline \multirow[t]{4}{*}{ 投動作得点（点） } & 学習前 & 22.02 & 12.25 & 28.50 & 18.55 \\
\hline & & 3.53 & 4.20 & 4.16 & 4.43 \\
\hline & 学習後 & 22.48 & 14.38 & 30.23 & 21.74 \\
\hline & & 3.25 & 3.04 & 3.35 & 4.06 \\
\hline
\end{tabular}

上段：平均值 下段：標準偏差 $* * \mathrm{p}<0.01$

投運動学習プログラム実施前後において，遠投 距離は， 2 年生女子および 5 年生女子において有 意な改善が認められた（2年生女子： $6.25 \pm$ $1.89 \mathrm{~m} \rightarrow 7.54 \pm 1.90 \mathrm{~m} ， 5$ 年生女子： $13.22 \pm$ $3.23 \mathrm{~m} \rightarrow 14.35 \pm 3.62 \mathrm{~m}$ ，いずれも $\mathrm{p}<0.01 ）$ が, 2 年生男子および 5 年生男子においては有意な改 善は認められなかった（2 年生男子：12.78 士 $3.96 \mathrm{~m} \rightarrow 13.58 \pm 3.75 \mathrm{~m}, 5$ 年生男子： $26.53 \pm$ $5.63 \mathrm{~m} \rightarrow 27.18 \pm 5.45 \mathrm{~m})$. また，投動作得点につ いては， 2 年生女子， 5 年生男子および 5 年生女 子において有意な改善が認められた（2年生女 子： $12.25 \pm 4.20$ 点 $\rightarrow 14.38 \pm 3.04$ 点, 5 年生男 子： $28.50 \pm 4.16$ 点 $\rightarrow 30.23 \pm 3.35$ 点, 5 年生女 子： $18.55 \pm 4.43$ 点 $\rightarrow 21.74 \pm 4.06$ 点）が, 2 年生 男子においては有意な改善は認められなかった $(22.02 \pm 3.53$ 点 $\rightarrow 22.48 \pm 3.25$ 点 $)$.

\section{2. 投運動学習プログラム実施による投能力お よび投動作の学習効果と体力および模倣能 カとの関係}

表 5 に，投能力および投動作（学習効果, 学習 前）と体力, 模倣能力との間の順位相関係数を示 した. 投能力の学習効果と学習前の投能力, 体力, および上肢・下肢模做能力との間で, 全群におい て，有意な相関関係は認められなかった。また， いずれの群においても, 投動作の学習効果と学習 前の投動作との間には有意な相関関係が認められ
( 2 年生男子 $: r=-0.346, p<0.05,2$ 年生女 子： $\mathrm{r}=-0.518, \mathrm{p}<0.01,5$ 年生男子： $\mathrm{r}=$ $-0.464, p<0.01,5$ 年生女子 : $r=-0.283$, $\mathrm{p}<0.05)$ ，学習前の投動作が未熟な者ほど，投 動作得点の伸びが大きかった。ささらに，投動作の 学習効果との間には，2年生男子では下肢模倣能 力が $(r=0.312, p<0.05), 5$ 年生男子では体力 が $(r=-0.301, p<0.05) ， ま た ， 5$ 年生女子で は下肢模做能力 $(\mathrm{r}=0.281, \mathrm{p}<0.05)$ が有意な 相関関係にあったが，2年生女子においては有意

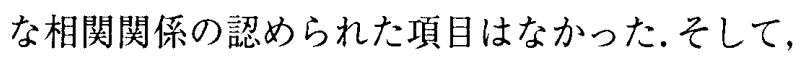
投動作の学習効果と投能力の学習効果との間に有 意な相関関倸が認められたのは，2 年生女子 $(\mathrm{r}=0.388, \mathrm{p}<0.01)$ 抢よび 5 年生男子（ $\mathrm{r}=$ $0.315, \mathrm{p}<0.05)$ であった.

学習前の投能力と体力との間には，2 年生男子 $(\mathrm{r}=0.411, \mathrm{p}<0.01), 5$ 年生男子 $(\mathrm{r}=0.348$ ， $\mathrm{p}<0.05)$ および 5 年生女子 $(\mathrm{r}=0.488, \mathrm{p}<0.01)$ において有意な相関関係が認められた。一方，学 習前の投能力と模倣能力との間には，上肢，下肢 のいずれにおいても，全群で有意な相関関係は認 められなかった。 また，学習前の投動作と体力と の間に相関関係が認められたのは，5年生男子 $(\mathrm{r}=0.308, \mathrm{p}<0.05)$ および 5 年生女子 $(\mathrm{r}=$ $0.342, \mathrm{p}<0.01)$ であった，学習前の投動作と上 肢模倣能力との間にはいずれの群においても有意 な相関関係が認められず，下肢模倣能力との間に 
表 5 遠投距離・投動作得点の学習効果と学習前の遠投距離・投動作得点, 体力および上肢・下肢模倣能力と の順位相関係数

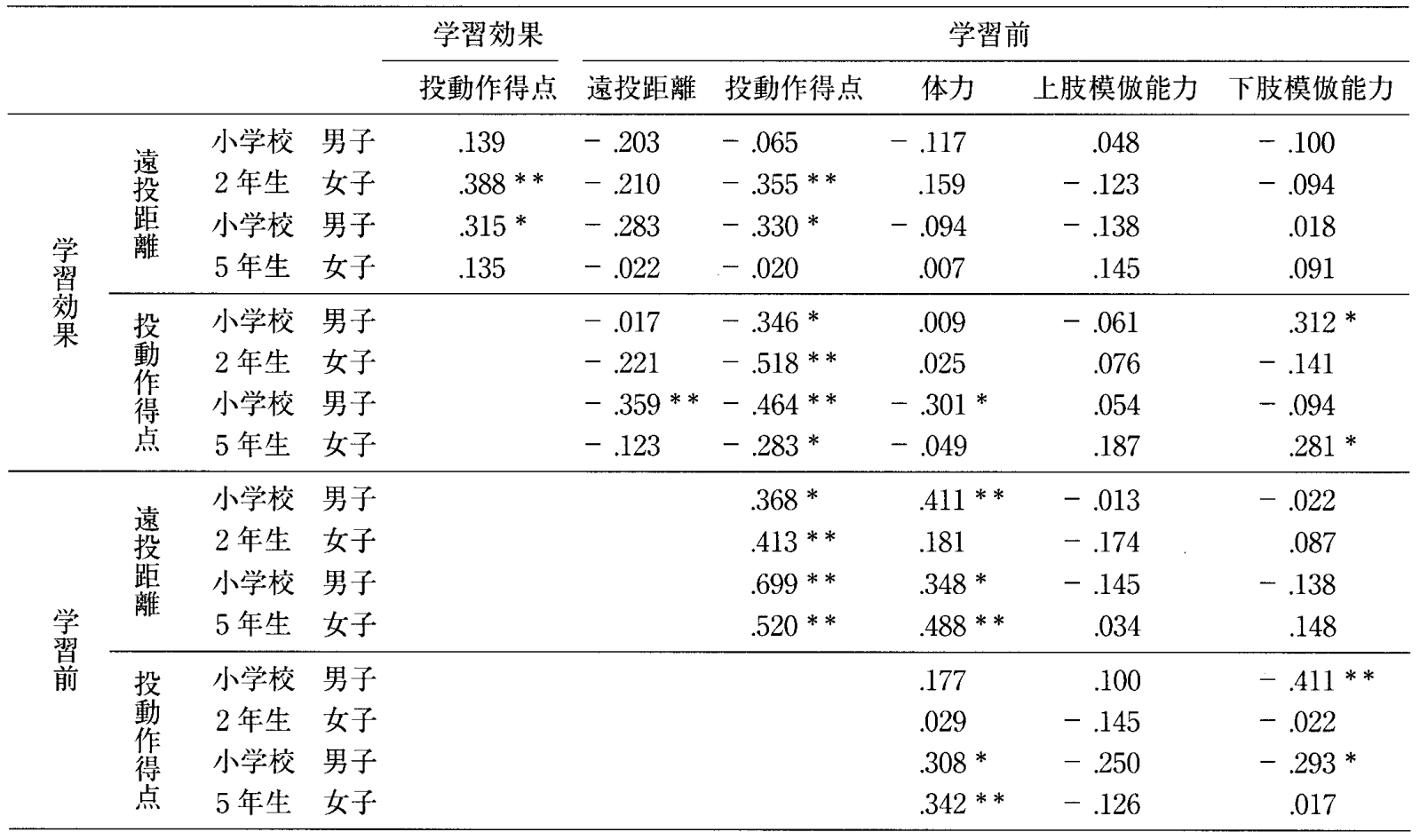

** $\mathrm{P}<0.01,{ }^{*} \mathrm{P}<0.05$

は， 2 年生男子 $(\mathrm{r}=-0.411, \mathrm{p}<0.01)$ および 5 年生男子（ $\mathrm{r}=-0.293, \mathrm{p}<0.05 ）$ で有意な相関 関係が認められた。

\section{IV 考察}

\section{1. 投運動学習による投能力および投動作の変 化}

学習プログラムの実施により，2 年生男子は遠 投距離および投動作得点はともに有意な改善がみ られず， 2 年生女子および 5 年生女子はともに有 意に改善され，5年生男子においては遠投距離の 有意な改善はみられなかったものの投動作得点の 有意な改善が認められた（表4）。

宮下ほか（1977）は投動作のトレーニング至適 時期は幼児期であると報告し， Nelson et al. （1986）も5才の段階で女子の遠投距離は男子の $57 \%$ あり，そのうちの $31 \%$ は動作習熟度の違 いであることを報告していることから，動作習熟 は幼児期に進むことが分かる.これらの報告から， 投動作は既に小学校就学以前に完成し，以後には
トレーナビリティが残されていないと考えられて いた，実際に，水野ほか（1976）の研究によると， 成人女性では遠投距離および投動作の改善はほと んどみられないということである.これに反して， 尾縣ほか（1996，2001）は，準備動作に強調を置 いた投運動学習を行えば，小学校 $2 \cdot 3$ 年生，女 子大学生においても投動作および遠投距離は改善 されるという指摘をしている，坚童期以降の投能 力のトレーナビリティの有無について意見が分か れる中，本研究に扔いて，2 年生女子（6.25 $1.89 \mathrm{~m} \rightarrow 7.54 \pm 1.90 \mathrm{~m})$ および 5 年生女子 $(13.22 \pm 3.23 \mathrm{~m} \rightarrow 14.35 \pm 3.62 \mathrm{~m})$ で遠投距離に, また， 2 年生女子（12.25 \pm 4.20 点 $\rightarrow 14.38 \pm 3.04$ 点), 5 年生男子 $(28.50 \pm 4.16$ 点 $\rightarrow 30.23 \pm 3.35$ 点 $)$ および 5 年生女子（18.55 \pm 4.43 点 $\rightarrow 21.74 \pm 4.06$ 点)で投動作得点に有意な改善の傾向が認められ， 有意な改善を示さなかった群においても改善の傾 向が見られたのは，尾縣ほか（1996，2001）の報 告を参考に投運動で重要な役割を果たす準備動作 に強調を置いた指導がなされたためと推測するこ とができる。すなわち，体育学習の現場において 
も，教師が動きのどの部分を重視し，どのような 教材を準備するかによって，学習効果が異なって くる可能性を示唆するものである。本研究では, 2 年生女子だけでなく，5年生女子にも遠投距離 および投動作得点の改善が認められており，尾縣 ほか（1996）の報告と合わせると，女子において は小学校全般そして女子大学生にいたるまでオー バーハンドスローのトレーナビリティがあること が明らかになったと言える。

両学年男女において, 学習前の投能力と投能力 の学習効果との間には有意な相関関係は認められ なかった．投能力に見られる学習効果は，学習前 の遠投距離が大きい者ほどその効果は大きいとい う報告（Dusenberry，1952；桜井，1991）があ るが，本研究では学習前の投能力と投能力の学習 効果との間に有意な相関関倸は認められなかっ た。そればかりか，投動作得点について見てみる
と，学習前の投動作と投動作の学習効果との間に は有意な相関関係が認められ（2 年生女子： $r=-0.518, p<0.01,2$ 年生男子 $: r=-0.346$, $\mathrm{p}<0.05,5$ 年生男子 : $\mathrm{r}=-0.464, \mathrm{p}<0.01,5$ 年生女子 $: r=-0.283, p<0.05)$, 学習前の投 動作得点の低い者の方が学習による投動作得点の 伸びが大きいという傾向が示された．図 4 は，2 年生女子と 5 年生男子における学習前後での投動 作得点の変化を個人毎に示したものである。この 図からは，投動作の未熟な児童において特に改善 が見られ，その結果，群全体の標準偏差も2年生 女子が 4.20 点から 3.04 点, 5 年生男子が 4.16 点か ら 3.35 点へと小さくなり，投動作得点のばらつき が小さくなったことが明らかである.このことは, 体力・運動能力の二極化が進み, 学習指導要領で も懸念すべき問題として取りあげられる現状にお いて，低い山に分布する児童の投能力を適切な学

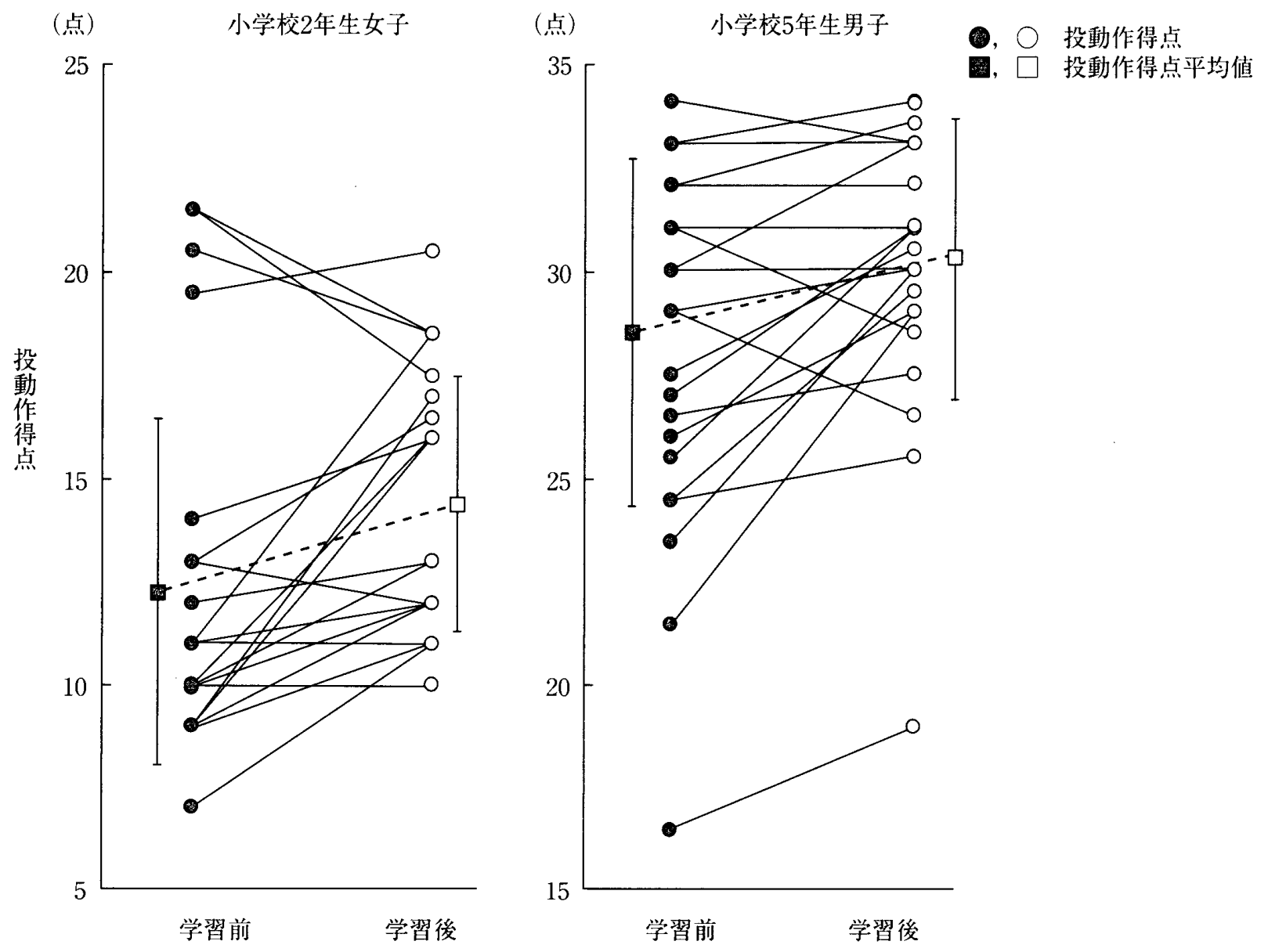

図4投運動学習プログラム実施前後における投動作得点の変化 一小学校 2 年生女子および小学校 5 年生男子を個人で見た場合一 
習によって高めることができるという可能性を示 していると言える。

\section{2. 投動作の学習効果に影響を及ぼす要因の検} 討

本研究では，要因間の相互関係を検証するため にKendallの順位相関分析を用いた。その理由は， ある特定の集団内での個々人の位置関係を把握す るためには順位相関の使用が適切であったためで ある。この方法は順位による評価であるため，測 定值の大きさは考慮されない。なかには，遠投距 離や投動作得点の低下を示した児童も存在した が，遠投距離および投動作得点の低下量あるいは 増加量を問題とするのではなく，「学習効果」の 違いを生む要因を検討するという本研究の目的を 達成することにおいては，Kendall順位相関分析 を用いることは妥当であると判断した。

2 年生男子および 5 年生女子では投動作の学習 効果と下肢模倣能力との間に有意な相関関係が認 められた。この 2 年生男子と 5 年生女子の学習前 の投動作得点は 20 点前後（2 年生男子 $22.02 \pm$ 3.53 点， 5 年生女子 $18.55 \pm 4.43$ 点）で，雨群に有 意差が認められず，ほぼ同じ投動作習熟度にある と考えられる。したがって，この程度の投動作習 熟度を示す集団においては，下肢模做能力が投動 作の学習効果の差を生む要因ともなっていること が示唆される。一方，投動作の学習効果と上肢模 做能力との間には有意な相関関係は認められなか った．高本ほか（2003）の，男女ともに児童期に おいては下肢模倣能力が投動作の習熟度に影響を 及ぼす要因の一つとして挙げられるが，上肢模做 能力は影響しないという指摘を参考にすると，投 動作の学習効果に対しても上肢よりも下肢の模倣 能力が強い影響を及ぼす可能性のあることが推察 できる，つまり，上肢は使用頻度が高く，多くの 子どもが必要な水準まで発達しているのに対し， 下肢は子どもによって使用頻度は異なるために， 発達の程度に差があると考えることができる。ま た，参考までに 2 年生男子においては，下肢模倣 能力と下肢の動きとして評価した足の踏み出しに 関する動作得点との間には有意な相関関係が認め
られている $(\mathrm{r}=-0.518, \mathrm{p}<0.05)$ ことからも， 下肢の模倣能力は，直接，投動作中の下肢の動き の改善に影響を及ぼす重要な要因になることも考 えられる。

本研究で得られた投動作の学習効果と下肢模倣 能力との関係から, 下肢模倣能力の発達は投運動 学習を効果的に進める上で重要であり, 体育学習 の中にも積極的に下肢の模倣的な運動を取り入れ るなどして，下肢の動き・動かし方を意識させる ことが必要であることが示唆として得られる。

成熟型に近い投動作レベルに達していると考え られる 5 年生男子においては，学習前の投能力と 体力との間に有意な正の相関関係が認められてお り（r=0.348, $\mathrm{p}<0.05)$ ，体力が優れている者ほ ど学習前の遠投距離が大きいという関係が認めら れた。出村（1993）は，成熟型の投動作が可能に なるとパワーや協応性などの体力要因が遠投距離 に影響を及ぼす重要な要因になると指摘してい る. 本研究の 5 年生男子が，出村（1993）の言う 成熟型の投動作に相当すると考えることができよ う.しかしながら，5年生男子においては体力と 投動作の学習効果との間には負の相関関係が認め られた（ $\mathrm{r}=-0.301 ， \mathrm{p}<0.05)$.また，体力は学 習前の投動作との間に有意な正の相関関係が $(\mathrm{r}=0.308, \mathrm{p}<0.05)$, 学習前の投動作は投動作 の学習効果との間に有意な負の相関関係が $(\mathrm{r}=-0.464, \mathrm{p}<0.01)$ 認められていることから， 体力レベルの低い児童は学習前の投動作習熟度が 低く，同じ学習を行っても投動作の学習効果が大 きくなったといえる。この理由を次のように考え ることができる．表1から分かるように，5年生 男子は群全体の平均值で見ると他の群に比較して 投動作，体力ともに高い。しかし，5年生男子の 群内で見てみると，なかには体力が低くて動作も 未習熟な個人も存在する。高本ほか（2003）は， 小学校 3 年生以降の男子においては, 体力の発達 が遠投距離の発達に影響していると報告してお り，男子では自然な発育の中でも，体力を投動作 のなかに活かせる時期がくることを示唆してい る. 本研究では，体力を投動作の中に活かすこと ができる学年段階にありながら，投動作の習熟度 
がわずかに低いために活かすことができていなか った男子児童が，学習による投動作の改善によっ て，ボールに対して力をうまく伝えられるように なった，あるいは力の発揮の夕イミングなどを習 得したなどといった体力を活かすコツをつかんだ 結果, 遠投距離が伸びたものと推察することがで きる。

5 年生男子と同様に，2年生女子においても投 動作の学習効果と投能力の学習効果との間に有意 な相関関係が認められた $(r=0.388, p<0.01)$. 2 年生女子は, 投動作習熟度が極めて低い児童の 集団であるが，投動作と投能力との間には有意な 相関関係が認められている $(\mathrm{r}=0.413, \mathrm{p}<0.01)$ ことから，この段階においても投動作の改善は重 要な要因であると考えることができる。また，投 動作の学習効果と体力・上肢掞よび下肢模做能力 との間には有意な関係が認められていない。これ らの結果から，遠投距離・投動作のいずれもが極 めて低い水準にあるために他の要因の影響を受け ず，適切に投動作を改善させることが投能力の改 善にもつながることを示唆していると考えられ る.

女児の投運動への参与が極めて低いという中村 （1994）の報告を参考にすると，2年生女子の投 能力・投動作の水準が極めて低い背景には, 就学 までの投運動の経験は少なく，また投げに関連す る動きの模倣経験も少ないことがあげられる。そ こで，2年生女子のような投能力・投動作が非常 に低い水準にある集団に対しては，本研究で用い たような投動作の改善に強調を置くゲーム的要素 を含んだ教材を取り入れていくことにより，投動 作に特別な意識を持たせないままに自然に動作や 能力を改善していくことが有効と言える.

\section{$V$ 要 約}

本研究は，小学校 2 年生男女 46 名および 5 年生 男女53名を対象として，投動作改善を目的とし た学習プログラムを実施し，そこに生じる学習効 果の差に影響を及ぼす要因について，学習前の体 力や模做能力の発達度および投動作の習熟度など
から検討することを目的とした。

本研究で得られた主な結果は以下のとおりであ る.

1） 2 年生男子および 5 年生女子の集団において は，下肢模做能力が投動作の学習効果に影響を及 ぼす要因の一つとなることが示唆された。

2） 2 年生女子においては, 投動作の学習効果 と体力・模倣能力との間には有意な相関関係が認 められていないことから，投能力・投動作のいず れも非常に低い水準にあるために体力や模做能力 の影響を受けず，適切に動作を改善させることが 投能力の改善にもつながることが示唆された。

3）5年生男子においては，体力レベルの低い 児童における投動作の学習効果が大きく，集団全 体として体力の発達がかなり進んでいる 5 年生男 子の集団では，体力が低い児童においても投動作 を改善させることは可能であることが示唆され た。

\section{文献}

出村慎一（1993）幼児期におけるボール遠投に対す る体力及び投動作の貢献度とその性差. 体育学研 究, $37: 339-350$.

Dusenberry, L. (1952) Study of the effect of training in ball throwing by children ages three to seven. Res. Quart., 23: 9-14.

海老原修・桜井伸二・宮下充正（1983）就学前児童

のスポーツ参与が投動作に及ほす影響について。

Jpn. J. Sports Sci., $2: 72-78$.

深代千之（1983）幼児の投球技能。体育の科学,

$33: 103-109$.

伊与田賢（1999）投能力向上をめざした教材・教

具・指導ことばの開発とその有効性の検討. 体育 授業研究, $2: 8-16$.

金 善應・松浦義行（1988）幼览及び児童における 基礎運動技能の量的変化と質的変化に関する研究. 体育学研究, $33: 27-38$.

松田岩男（1979）運動技能の指導と言語教示や示範.

体育の科学, $29: 444-446$.

宮下充正・桜井伸二・齊田ゆかり（1977）幼坚にみ られるボール投げの練習効果. 昭和 52 年度日本体 育協会スポーツ科学研究報告, $4: 32-33$. 
水野忠和・角田俊幸 - 过 博明 - 宮下充正 (1976) 成人女子及び 18 歳女子の投能力. 昭和 51 年度日本 体育協会スポーツ科学研究報告, 3：24-28.

文部省 (1998) 小学校学習指導要領.

中村和彦（1994）子供の遊びはどう変わったのか. 学校体育, 47 (3)：66-69.

Nelson, J.K., Thomas, J.R., Nelsonm, K.R., and Abraham, P.C. (1986) Gender differences in children's throwing performance--Biology and environment--. Res. Quart. Exerc. Sports, 57: 280-287.

尾縣 貢 ・岡沢祥訓 - 関岡康雄 (1992) 走運動学習 における言語教示と示範の有効性に関する研究. 陸上競技研究, $10: 2-12$.

尾縣 貢・関岡康雄（1994）遠投に打ける投射角度 の変化が投射初速度，投射高および投動作に及ぼ す影響。スポーツ教育学研究，14：49-59.

尾縣 貢 - 関岡康雄 - 飯田 稔（1996）成人女性に おける投能力向上の可能性. 体育学研究, 41 : $11-22$.
尾縣 貢 - 高橋健夫 - 高本恵美 - 細越淳二 - 関岡康 雄（2001）オーバーハンドスロー能力改善のため の学習プログラムの作成：小学校 $2 \cdot 3$ 年生を対象 として。体育学研究, 46：281-294.

奥野暢道・後藤幸弘・辻野 昭 (1989）小中学生の オーバーハンドスローの練習効果について．第 9 回 バイオメカニクス学会大会論集, pp. 119-125.

桜井伸二（1991）投げる科学．大修館書店：東京.

Scamon, R.E. (1930) The measurement of man. Univ Minnesota press.

高本恵美 - 出井雄二 ・尾縣 貢 (2003) 小学校児童 における走，跳および投動作の発達：全学年を対 象として、スポーツ教育学研究, $23: 1-15$.

高本恵美 - 出井雄二 ・ 尾縣 貢 (2003) 小学校児童 の模倣能力と走・跳・投運動能力および動作との 関係。いばらき健康・スポーツ科学, $21 ： 11-21$. $\left(\begin{array}{l}\text { 平成 } 15 \text { 年 } 6 \text { 月 } 24 \text { 日受付 } \\ \text { 平成 } 16 \text { 年 } 1 \text { 月 } 10 \text { 日受理 }\end{array}\right)$ 